Maria Grazia Andreassi - Nicoletta Botto $\cdot$ Franca Cocci Debora Battaglia $\cdot$ Elisabetta Antonioli $\cdot$ Serena Masetti Samantha Manfredi · Maria Giovanna Colombo Andrea Biagini · Aldo Clerico

\title{
Methylenetetrahydrofolate reductase gene C677T polymorphism, homocysteine, vitamin B12, and DNA damage in coronary artery disease
}

Received: 12 June 2002 / Accepted: 10 September 2002 / Published online: 13 November 2002

(C) Springer-Verlag 2002

\begin{abstract}
Elevated levels of plasma homocysteine (Hcy), a risk factor for coronary artery disease (CAD), can result from genetic errors, e.g., the methylenetetrahydrofolate reductase (MTHFR) polymorphism, or nutrional deficiencies, e.g., in vitamin B12 and folate. The mechanism by which Hcy induces atherosclerosis is not fully understood. Recently, Hcy has also been observed to induce DNA damage. In this study, we have investigated whether DNA damage is related to the C677T variant in the MTHFR gene and to plasma levels of Hcy, B12, and folate in patients with CAD. Patients $(n=46)$ with angiographically proven CAD were studied by using the micronucleus (MN) test, an accepted method for evaluating genetic instability. TT patients had plasma Hcy levels higher than those with the CT or CC genotypes (27.8 \pm 5.2 vs $13.7 \pm 2.2$ and $12.9 \pm 1.9 \mu \mathrm{mol} / \mathrm{l}$, respectively; $P=0.02$ ). Patients with

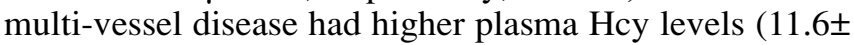
$1.2,22.0 \pm 4.7,19.3 \pm 3.9 \mu \mathrm{mol} / \mathrm{l}$ for one-, two- and threevessel disease, respectively; $P=0.05)$. The $M N$ index increased with the number of affected vessels $(8.4 \pm 0.7$, $11.1 \pm 2.0,14.2 \pm 1.7$ for one-, two-, and three-vessels disease, respectively; $P=0.02$ ) and was significantly higher in subjects with the TT genotype compared with the CC or CT genotypes $(15.7 \pm 2.4$ vs $8.9 \pm 1.7$ and $9.9 \pm 0.8 ; P=$ $0.02)$. The MN index was also correlated negatively with plasma B12 concentration $(r=-0.343 ; P=0.019)$ and positively with plasma Hcy $(r=0.429, P=0.005)$. These data indicate that the $\mathrm{MN}$ index is associated with the severity of CAD and is related to the MTHFR polymorphism, suggesting an interesting link between coronary atherosclerosis and genetic instability in humans.
\end{abstract}

M.G. Andreassi $(\bowtie) \cdot$ N. Botto $\cdot$ E. Antonioli $\cdot$ S. Masetti

S. Manfredi - M.G. Colombo · A. Biagini · A. Clerico Laboratory of Cellular Biology,

CNR Institute of Clinical Physiology, G. Pasquinucci Hospital,

Via Aurelia Sud-Montepepe, 54100 Massa, Italy

e-mail: andreas@ifc.pi.cnr.it

F. Cocci · D. Battaglia

CNR Institute of Clinical Physiology, Pisa, Italy

\section{Introduction}

Coronary artery disease (CAD) is a multifactorial disease that appears to depend on the interaction between environmental risk factors and multiple predisposing genes. On a genetic level, functional allelic variations or polymorphisms in humans may play a role in an individual's susceptibility to the manifestation of the disease.

Recently, several pieces of evidence have suggested that the occurrence of somatic DNA alterations contributes significantly to the pathogenesis of the disease (De Flora et al. 1997; Van Schooten et al. 1998; Andreassi et al. 2000; Botto et al. 2001; Izzotti et al. 2001; J. S. Ross et al. 2001). Indeed, in accordance with the monoclonal hypothesis (Benditt and Benditt 1973), the intimal hyperplasia of smooth muscle cells, i.e., the pathologic process that underlies atherosclerosis and restenosis, may be driven by molecular events that confer a selective growth advantage on the cell, similar to the process of human cancer development. Thus, it is reasonable to hypothesize common pathophysiologic pathways in such different disorders as cancer and atherosclerosis.

Methylenetetrahydrofolate reductase (MTHFR) is a key enzyme in homocysteine (Hcy) metabolism and seems to play a role in both cancer and cardiovascular disease (Fletcher and Kessling 1998; Piyathilake et al. 2000; Song et al. 2001). MTHFR is responsible for the circulating form of folate, 5-methyl-tetrahydrofolate, which provides methyl groups for the remethylation of Hcy to methionine and S-adenosyl methionine, the common methyl donor for the maintenance of DNA methylation.

The C677T polymorphism in the MTHFR gene is associated with reduced enzyme activity (Frosst et al. 1995). It is now well-established that the TT genotype is also associated with increased Hcy levels (Jacques et al. 1996; Kluijtmans et al. 1997). Although the relationship between the $677 \mathrm{~T}$ variant and CAD risk is not clearly established at present, the MTHFR polymorphism may play an important role in the pathophysiology of cardiovascular disease because of its influence on plasma Hcy levels. Al- 
ternatively, an increase in plasma Hcy levels may occur as a result of nutrional deficiencies in essential cofactors or enzyme substrates, including vitamin B12, folate, and/or vitamin B6.

Hyperhomocysteinemia has been identified as an independent risk factor for cerebral, coronary, and peripheral atherosclerosis, although the pathological mechanism of this risk is not fully understood. High plasma levels of Hcy are also associated with an increased risk of neural defects (Wenstrom 2000), Alzheimer's disease, and loss of cognitive functions (Miller 2000; Breteler 2000). Interestingly, several studies have also shown that Hcy can induce DNA damage (Kruman et al. 2000; Huang et al. 2001) suggesting a further mechanism by which increased levels of Hcy may contribute to the pathogenesis of the atherosclerosis and neurodegenerative diseases. In addition, recent observations indicate that plasma Hcy levels are positively correlated with baseline levels of genetic damage, as measured by the cytokinesis-block micronucleus (MN) assay (Fenech et al. 1997, 1998).

In numerous studies, the cytokinesis-block MN assay has been shown to be a reliable and sensitive biomarker for evaluating spontaneous and mutagen-induced DNA damage (Fenech 1993). We have previously demonstrated an increase of MN frequency that is positively correlated with the severity of CAD (Botto et al. 2001). The aim of this study has been to investigate whether DNA damage, as assessed by use of MN assay in human lymphocytes, is related to MTHFR polymorphisms and to plasma levels of Hcy, B12, and folate in patients with CAD.

\section{Materials and methods}

\section{Nomenclature}

Gene symbols used in this article follow the recommendations of the HUGO Gene Nomenclature Committee (Povey et al. 2001).

\section{Study population}

Forty-six patients with angiographically proven CAD (41 male and 5 female; mean age: $55.8 \pm 1.1$ years) were recruited from the Clinical Cardiology Department of our Institute (CNR Institute of Clinical Physiology, G. Pasquinucci Hospital). The severity of CAD was determined by the number of involved coronary arteries and by the number of lesions with more than $50 \%$ stenosis. Each angiogram was reviewed by two cardiologists who were unaware that the patients were enrolled in the study. Patient exclusion criteria were acute or chronic inflammatory disease, immunological disease, and history or presence of neoplastic disease. Medications used by patients generally included nitrates, oral aspirin, calciumchannel blockers, and acetylcholine esterase inhibitors. No patients were undergoing vitamin therapy.

After an 8-h fast, blood was drawn from patients for the MN assay and for the determination of the MTHFR genotype and plasma levels of Hcy, vitamin B12, and folate. At the time of blood sampling, all participants gave a complete medical history that included cardiovascular risk factors, such as smoking habits, hypertension, diabetes, dyslipidemia, and family history of CAD. Hypertension was defined as a blood pressure of more than 140/90 $\mathrm{mmHg}$ or based on the use of antihypertensive medication. Subjects with a history of diabetes or those receiving any antidiabetic medication were considered to be diabetic. Subjects were deemed dyslipidemic when their total cholesterol concentration was $220 \mathrm{mg} / \mathrm{dl}$ or their triglyceride concentration was $200 \mathrm{mg} / \mathrm{dl}$, or if they were receiving lipid-lowering drugs. Smoking history was coded by grouping patients into non-smokers who had never smoked and those who were or had been smokers. A positive family history was considered when a first-degree relative with CAD was present at the age of 55 years for men and 65 years for women.

Measurement of plasma levels of Hcy, vitamin B12, and folate

The plasma levels of Hcy, vitamin B12, and folate were assessed by use of commercially available kits (IMX system, Abbott Laboratories, Diagnostic Division, Abbott Park, Ill., USA). The reference ranges for these methods in our laboratory were: Hcy $=4.45-$ $12.42 \mu \mathrm{mol} / \mathrm{l}$; vitamin B12 $=179-1132 \mathrm{pg} / \mathrm{ml}$; folate $=3.1-12.4 \mathrm{ng} /$ $\mathrm{ml}$. Intra-assay and inter-assay coefficients of variation were: Hcy = $1.83 \%$ and $4.33 \%$; vitamin $\mathrm{B} 12=4.2 \%$ and $7.4 \%$; folate $=3.8 \%$ and $5.1 \%$, respectively.

\section{MTHFR genotype analysis}

According to a previously described procedure (Frosst et al. 1995), genotyping for the MTHFR point polymorphism C677T was performed by polymerase chain reaction amplification with the primers 5'TGAAGGAGAAGGTGTCTGCGGGA3' (sense) and 5'AGGACGGTGCGGTGAGAGTG3' (antisense). Thirty cycles $\left(95^{\circ} \mathrm{C}\right.$ for $45 \mathrm{~s}, 64^{\circ} \mathrm{C}$ for $30 \mathrm{~s}, 72^{\circ} \mathrm{C}$ for $30 \mathrm{~s}$ ) were used to amplify the 198 -bp product. Because the $\mathrm{C}$ to $\mathrm{T}$ transition at nucleotide 677 produces a HinfI digestion site, the amplified product derived from the mutant gene was cleaved into 175-bp and 23-bp fragments by HinfI, which leaves the wild-type gene unaffected. After electrophoresis through $6 \%$ polyacrylamide gel, the digestion products were visualized by staining with ethidium bromide.

\section{Lymphocyte preparation and $\mathrm{MN}$ assay}

Peripheral blood was collected by using heparin as an anticoagulant. The cellular cultures from each subject were set up by mixing $0.3 \mathrm{ml}$ whole blood with $4.7 \mathrm{ml}$ RPMI 1640 medium (GIBCO), supplemented with $10 \%$ fetal calf serum (GIBCO), $1.5 \%$ phytohemagglutin (PHA; GIBCO), and antibiotics (penicillin $100 \mathrm{IU} / \mathrm{ml}$ and streptomycin $100 \mathrm{mg} / \mathrm{ml}$; Sigma, St. Louis, USA). All cultures were incubated at $37^{\circ} \mathrm{C}$ in a humidified atmosphere of $5 \% \mathrm{CO}_{2}$ in air. For evaluation of $\mathrm{MN}$ frequency, cells were blocked in cytokinesis at the 44th hour, by adding cytochalasin B $(6 \mu \mathrm{g} / \mathrm{ml}$ final concentration; Sigma). Cell cultures were then harvested at the 72th hour. Harvesting of cells, hypotonic treatment, fixation, and slide preparation were performed according to the method previously described (Botto et al. 2001); fixed cells were then dropped onto clean microscopic slides, air dried, and stained by the Giemsa technique.

\section{Slide scoring}

For each sample, 1000 binucleated cells were scored blindly under the optical microscope (final magnification: 400×) for MN analysis. MN frequency was expressed as the number of micronucleated binucleated cells (MNBN), containing one or more MN, per 1000 cells.

\section{Statistical analysis}

All statistical analyses were conducted by means of the Statview statistical package, version 5.0.1, (SAS Institute, Cary, N.C.). Because of the skewness of the distributions of value for MN, Hcy, folate, and vitamin B12, analyses were performed by using the logarithmic transformation of data. Differences between the means of the two continuous variables were evaluated by Student's $t$-test. 
Table 1 Characteristics of patients according to MTHFR genotype

\begin{tabular}{lllll}
\hline \multicolumn{4}{l}{ MTHFR genotype } & \\
\cline { 2 - 5 } & $\begin{array}{l}\mathrm{CC} \\
(n=13)\end{array}$ & $\begin{array}{l}\mathrm{CT} \\
(n=22)\end{array}$ & $\begin{array}{l}\mathrm{TT} \\
(n=11)\end{array}$ & $\begin{array}{l}P \text { - } \\
\text { value }\end{array}$ \\
\hline Age (years) & $57.5 \pm 2.0$ & $53.8 \pm 1.3$ & $57.8 \pm 2.7$ & 0.19 \\
Gender & & & & 0.07 \\
Male & 10 & 22 & 9 & \\
Female & 3 & 0 & 2 & \\
Smoking & & & & 0.43 \\
Smokers & 7 & 16 & 6 & \\
No-smokers & 6 & 6 & 5 & \\
Diabetes & 2 & 4 & 3 & 0.75 \\
Dyslipidemia & 9 & 19 & 8 & 0.43 \\
Hypertension & 6 & 13 & 6 & 0.76 \\
Family history of CAD & 6 & 11 & 4 & 0.76 \\
No. of involved vessels & $1.8 \pm 0.2$ & $1.6 \pm 0.2$ & $2.4 \pm 0.2$ & 0.07 \\
No. of lesions & 2.8 & 3.3 & 4.7 & 0.08 \\
\hline
\end{tabular}

The data for the three or more independent groups were investigated by analysis of variance (ANOVA), and the significant differences among a group of means were tested by Scheffe's test. Scheffe's test was chosen for multiple comparisons because it is generally considered to be one of the most conservative tests and also because it is robust to violations of the assumptions typically associated with the multiple comparisons procedure (Snedecor and Cocharn 1980). The relationship between two different parameters was obtained by simple regression analysis. Multiple regression analysis was used to evaluate the independent determinants of $\mathrm{MN}$ levels. A $P$-value of 0.05 was considered statistically significant. The results were expressed as the mean $( \pm$ SEM) values.

\section{Results}

Study group characteristics and distribution of MTHFR $677 \mathrm{C} / \mathrm{T}$ polymorphism

The distribution of the MTHFR genotype in our population was compatible with the Hardy-Weinberg equilibrium. The $\mathrm{T}$ allele frequency was $47.8 \%$; the genotype frequencies were $28.2 \%, 47.8 \%$, and $23.9 \%$ for CC, CT, and TT, respectively.

Table 1 summarizes the characteristics of the patients according to MTHFR genotype. One-, two-, and threevessel disease was observed in 19,12 , and 15 patients, respectively. There were no significant differences among MTHFR genotypes regarding the prevalence of traditional risk factors, although the number of involved vessels and the number of coronary lesions tended to be higher in TT homozygotes $(P=0.07$ and $P=0.08)$.

MTHFR genotype and plasma levels of Hcy, B12, and folate

The plasma levels of Hcy according to MTHFR genotype are reported in Fig. 1. Hcy levels $(27.8 \pm 5.2 \mu \mathrm{mol} / \mathrm{l}$ for TT,

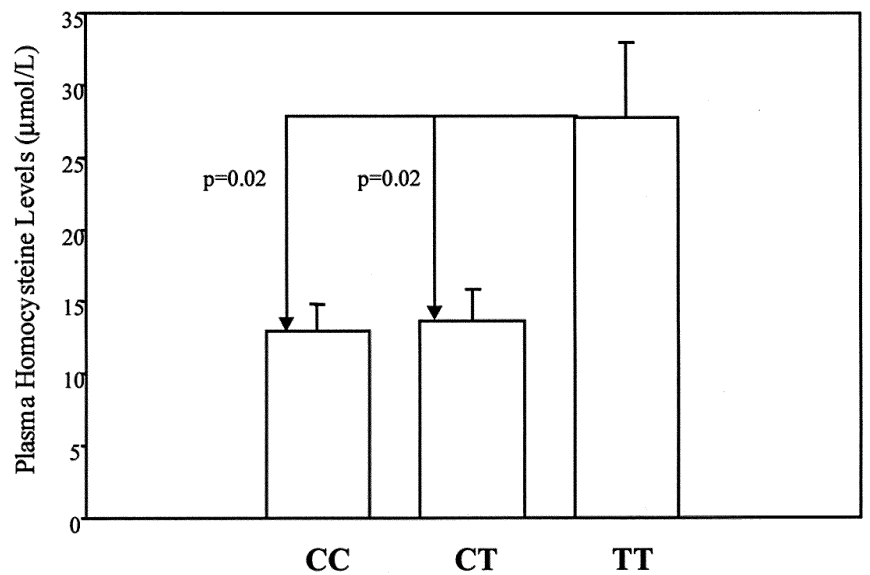

Fig. 1 Plasma levels of Hcy in relation to C677T MTHFR genotypes

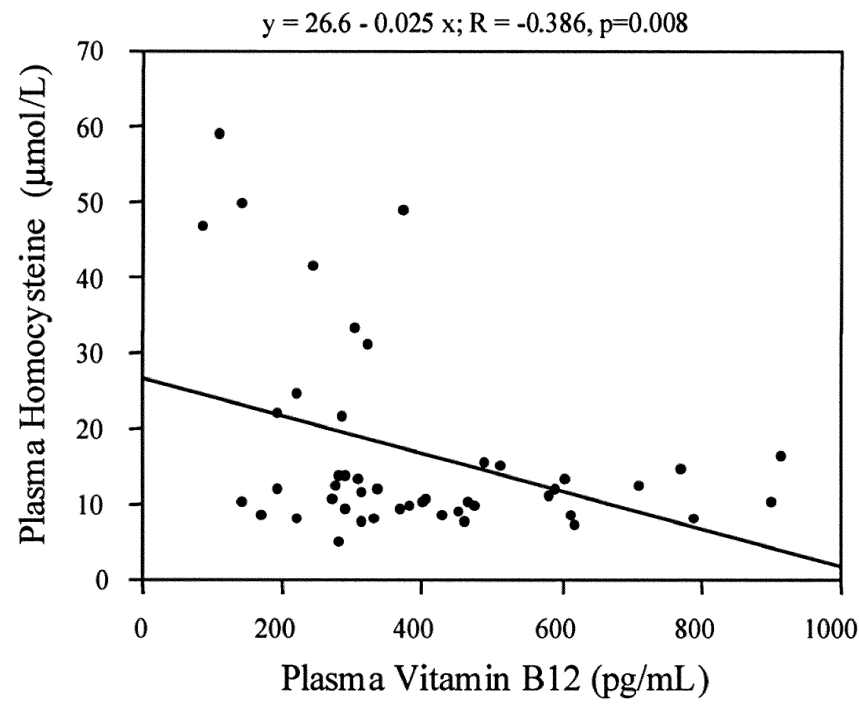

Fig. 2 Relationship between plasma levels of Hcy and vitamin B12

$13.7 \pm 2.2 \mu \mathrm{mol} / \mathrm{l}$ for $\mathrm{CT}$, and $12.9 \pm 1.9 \mu \mathrm{mol} / \mathrm{l}$ for $\mathrm{CC}$ ) were significantly higher in patients with the TT genotype than in those with the $\mathrm{CC}(P=0.02)$ or $\mathrm{CT}(P=0.02)$ genotype.

B12 plasma levels in patients with TT tended to be lower than in those with the CC or CT genotype, but

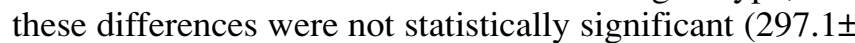
$51.4 \mathrm{pg} / \mathrm{ml}, 414.3 \pm 41.3 \mathrm{pg} / \mathrm{ml}$, and $440.4 \pm 62.8 \mathrm{pg} / \mathrm{ml}$ for TT, CT, and CC, respectively). Plasma folate levels were not significantly different among the three genotypes (4.0 \pm $0.6,4.2 \pm 0.3$, and $3.9 \pm 0.4 \mathrm{ng} / \mathrm{ml}$, for TT, CT, and CC, respectively). However, there was no significant difference between genotypes in individuals with folate greater than $3.1 \mathrm{pg} / \mathrm{ml}$. Conversely, among individuals with folate less than $3.1 \mathrm{pg} / \mathrm{ml}$, Hcy levels was significantly increased in TT homozygotes $(43.7 \pm 3.8 \mathrm{pg} / \mathrm{ml}, n=4, P=0.0005)$ and CT heterozygotes $(22.0 \pm 9.3 \mathrm{pg} / \mathrm{mL}, n=5, P=0.02)$ with respect to CC subjects $(9.6 \pm 0.4 \mathrm{pg} / \mathrm{ml}, n=6)$.

Moreover, Hcy concentrations were inversely and significantly associated with concentrations of B12 $(r=-0.386$, 


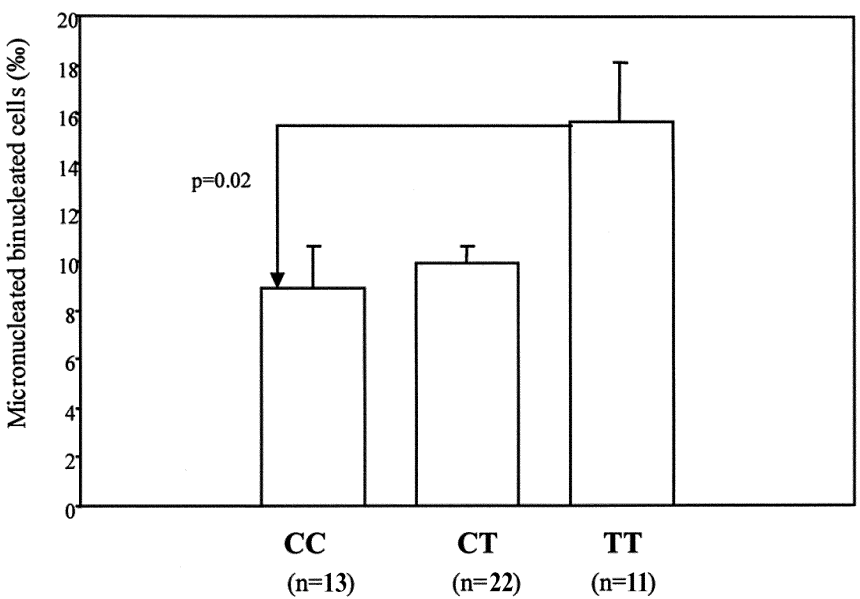

Fig. 3 MN frequency in relation to the C677T MTHFR genotypes

$P=0.0081$; Fig. 2) and weakly associated with folate concentrations $(r=-0.264, P=0.077)$. Plasma Hcy levels were higher in patients with multi-vessel disease (11.6 \pm 1.2 , $22.0 \pm 4.7,19.3 \pm 3.9 \mu \mathrm{mol} / \mathrm{l}$ for one-, two-, and three-vessel disease, respectively; $P=0.05$ )

Relationship between MN levels, CAD, and MTHFR genotypes

The mean MN frequency increased with the number of affected vessel $(8.4 \pm 0.7 \% o, 11.1 \pm 2.0 \%, 14.2 \pm 1.7 \%$, for one-, two-, and three-vessel disease, respectively). Scheffe's test after ANOVA showed that the MN frequency was significantly higher in three-vessel compared with one-vessel disease $(P=0.02)$. As shown in Fig. 3 , MN frequency was significantly higher in subjects with the TT genotype than in those with the CC genotype $(P=0.02)$. Even after the exclusion of the subjects with low levels of both B12 $(<179 \mathrm{pg} / \mathrm{ml})$ and folate $(<3.1 \mathrm{ng} / \mathrm{ml})$, TT homozygotes had a greater MN frequency compared with the other genotypes $(15.7 \pm 3.6,9.2 \pm 0.6$, and $8.1 \pm 3.0$, for TT, CT, and $\mathrm{CC}$ respectively; $P=0.049)$.

Relationship between MN levels and plasma Hcy, folate, B12 levels

$\mathrm{MN}$ frequency was not significantly correlated with plasma folate $(r=0.144, P=0.34)$, but there was a significant $(P=0.019)$ negative correlation with plasma B12 $(r=-0.343$; Fig. 4). Interestingly, $\mathrm{MN}$ frequency and plasma Hcy were also significantly $(P=0.005)$ and positively correlated $(r=0.429)$ in those subjects who were not deficient in B12. However, multivariate linear regression revealed that the number of affected vessels $(P=0.01)$ and vitamin B12 plasma levels $(P=0.05)$ were independently correlated with MN frequency, whereas TT genotypes appeared to be only a "borderline" independent factor $(P=0.08)$ in our population a)
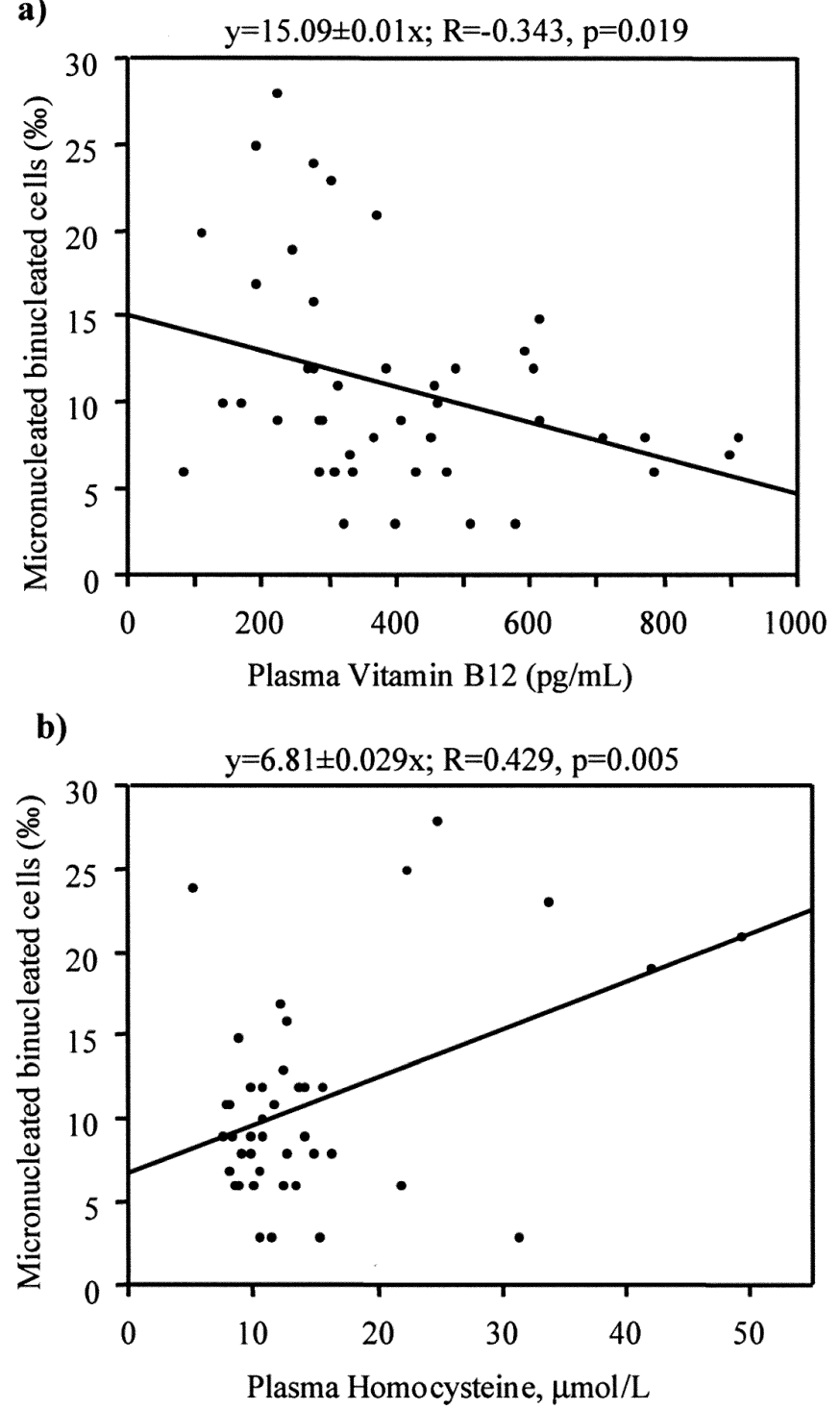

Fig. 4a, b Relationship between MN frequency and plasma levels of Hcy (a) and vitamin B12 (b)

\section{Discussion}

This study suggests that the MTHFR genotype and the levels of plasma Hcy and B12 may be important determinants of genetic instability in CAD. The potential role of DNA damage in atherosclerosis represents an important issue that is still not fully understood. The "inflammatory response to injury" is the foremost theory in the pathogenesis of atherosclerosis (R. Ross 1999). However, various evidence suggests that cancer and atherosclerosis share common pathogenetic mechanisms, and that DNA alterations also contribute significantly to the pathogenesis of atherosclerosis (Andreassi et al. 2000; J. S. Ross et al. 2001).

Recently, the generation of oxygen free radicals has been suggested as an important cause of DNA damage in 


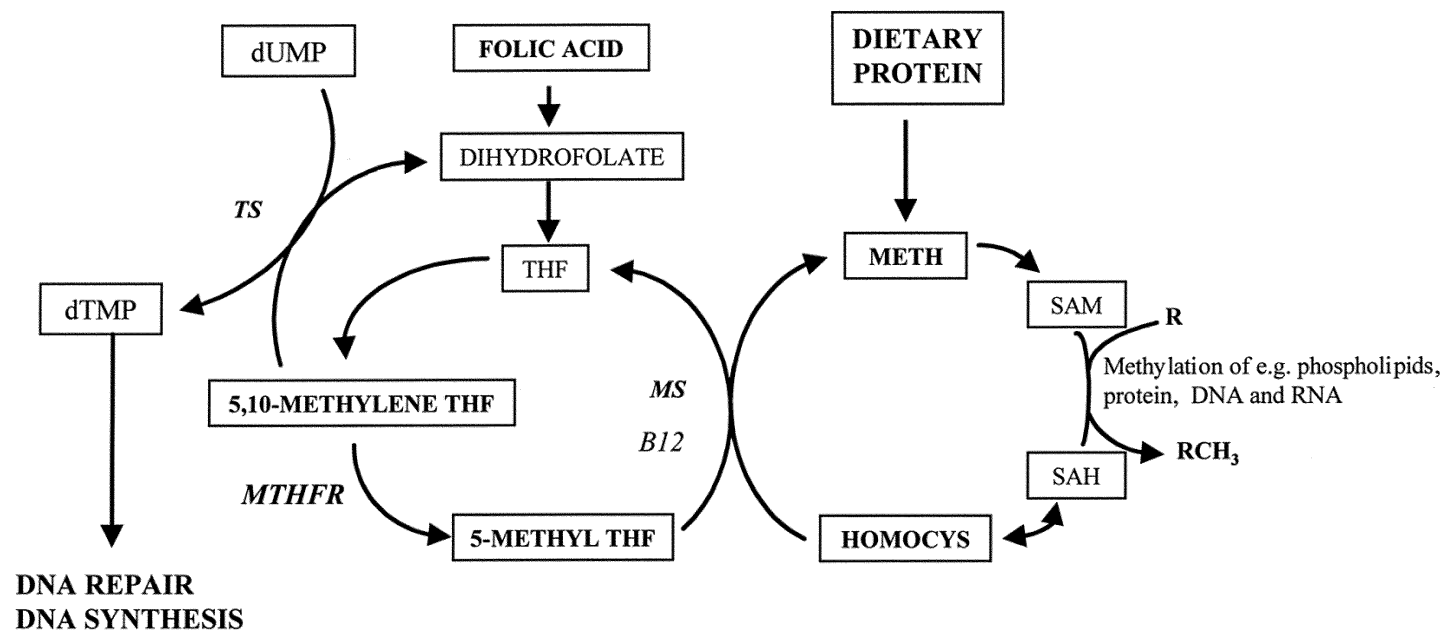

Fig. 5 Possible mechanism of DNA alterations in Hcy metabolism may include a decrease in the synthesis of thymidylate (dTMP) with accumulation of dUMP and incorporation of uracil into DNA instead of thymine and/or alterations in the normal maintenance of DNA methylation (B12 vitamin B12, HOMOCYS Hcy, METH methionine, THF tetrahydrofolate, $T S$ thymidylate synthase, $M S$ methionine synthase, MTHFR methylenetetrahydrofolate reductase, $S A M$ S-adenosylmethionine, SAH S-adenosyl homocysteine). Modified from Fenech (2001)

atherosclerosis (Bennet 2001; Lee and Blair 2001; Martinet et al. 2002). We have previously shown (Botto et al. 2001) that an increase of MN frequency is positively correlated with the severity of the CAD. Moreover, our recent observations have indicated that further oxidative DNA damage is produced in the peripheral lymphocytes of patients undergoing percutaneous coronary angioplasty, damage probably related to ischemia-reperfusion oxidative injury (Andreassi et al. 2002).

We have designed the present study to evaluate the effect of Hcy levels on DNA damage and the impact of the MTHFR C677T mutation on this damage. We report allelic and genotypes frequencies of the MTHFR gene similar to those previously described in patients with CAD (Morita et al. 1997; Mager et al. 1999). Our study provides evidence for the first time that the MTHFR TT genotype is strictly associated with DNA alterations in patients with $\mathrm{CAD}$. In addition, the MN frequency is correlated negatively with plasma B12 concentration and positively with plasma Hcy. These results are in agreement with those reported by Fenech et al. $(1997,1998)$, who have observed a positive correlation between plasma Hcy and MN index and a negative relationship between MN and serum B12, but no significant correlation between $\mathrm{MN}$ and folate status, in general populations.

Putative mechanisms of atherothrombosis induced by Hcy include endothelial dysfunction, increased platelet adhesion, and proliferation of vascular smooth muscle cells (Thambyrajah and Townend 2000). Moreover, high concentrations of Hcy are known to produce autooxidation with the production of hydrogen peroxide $\left(\mathrm{H}_{2} \mathrm{O}_{2}\right)$, a harmful reactive oxygen metabolite (Starkebaum and Harlan 1986; Loscalzo 1996).
Thus, an increased production of reactive oxygen species may also be involved in Hcy-mediated DNA damage. Indeed, a recent study has shown that Hcy induces apoptotic DNA damage mediated by increased intracellular generation of $\mathrm{H}_{2} \mathrm{O}_{2}$ (Huang et al. 2001). Interestingly, $\mathrm{H}_{2} \mathrm{O}_{2}$ is known to induce necrosis and $\mathrm{MN}$ in human lymphocytes (Crott and Fenech 1999). Furthermore, a genotoxic potential of high concentrations of Hcy has been recently described, although this experiment utilized a regime of acute exposure to Hcy in vitro (Crott and Fenech 2001).

On the other hand, the genotoxic action of hyperhomocysteinemia may be an indirect marker of biological mechanisms associated with excessive misincorporation of uracil into DNA in the presence of nutrional deficiences and/or the process of DNA methylation (Fig. 5). Indeed, several lines of evidence suggest that the excessive misincorporation of uracil in DNA results in point mutation, DNA and chromosome breaks, and MN formation (Fenech 2001; Blount et al. 1997). Most importantly, a recent study in an experimental model of knockout mice indicated that MTHFR deficiency is associated with hyperhomocysteinemia and global DNA hypomethylation in several tissues with neuropathology and aortic lipid deposition (Chen et al. 2001). Furthemore, recent human studies have also shown that the TT MTHFR genotype is associated with genomic DNA hypomethylation, a characteristic of most cancers (Stern et al. 2000; Friso et al. 2002; Singal and Ginder 1999).

However, the available data indicate important differences with respect to the association of the TT genotype MTHFR with cancer risk susceptibility. On the one hand, the MTHFR T variant may be linked to a reduced risk for cancer because of the reduced MTHFR activity, which may provide more 5,10-MTHF available for the synthesis of thymine, thus preventing the misincorporation of uracil into DNA (Ma et al. 1997; Skibola et al. 1999); on the other hand, there is evidence that the TT genotype is associated with increased cancer risk, particularly in relation to low dietary intake of folic acid, methionine, and vitamins B12 and B6 (Piyathilake et al. 2000; Song et al. 2001; Esteller et al. 1997; Gershoni-Baruch et al. 2000; 
Ulvik et al. 2001). Furthemore, experimental results do not appear to support the hypothesis that the C677T polymorphism protects against uracil incorporation into DNA (Crott et al. 2001a). Crott et al. (2001b) have also not found an effect of the MTHFR C677T polymorphism on DNA damage by using the MN assay. However, we have now found a significant association between TT genotype and increased MN levels. At present, we cannot explain clearly these conflicting results, which might be associated with the higher plasma Hcy concentrations in patients than those in normal controls.

In conclusion, these data suggest that the association of MTHFR C677T polymorphism with hyperhomocysteinemia, nutrional deficiencies, and oxidative stress may be a plausible molecular mechanism of genetic instability in atherosclerotic lesions. However, some limitations of this study should also be considered. First and foremost is that our observations are based on relatively few individuals, and the possibility that DNA damage may occur by many routes, such as atherogenic risk factors (dyslipidemia, diabetes, smoking) and environmental insults should also be considered. In addition, no direct correlations between DNA damage and Hcy in vitro experiments have been examined in this study. Consequently, the higher MN frequency observed in our patients may be caused by factors other than by TT homozygosity or high plasma Hcy levels and low plasma B12 concentrations. Nevertheless, our study was performed to explore a potential between somatic DNA damage, nutrional deficiencies (vitamin B12 and folate), Hcy, and MTHFR genotype in a population of patients with CAD rather being "homogeneous" for various atherogenic risk factors. Therefore, these limitations do not belittle the main observation of our study, which encourages additional work in this area. Additional studies with a large sample size should be performed to confirm these observations. In particular, it would be of interest to clarify the influence of therapy lowering plasma Hcy in the prevention of simultaneous DNA damage and restenotic coronary lesions. In addition, our findings should encourage further studies for defining the genotoxic potential of Hcy in a variety of cell types, especially those of the human cardiovascular system (e.g., smooth muscle cells, endothelial cells), in order to clarify its involvement in the pathogenesis of atherosclerosis.

\section{References}

Andreassi MG, Botto N, Colombo MG, Biagini A, Clerico A (2000) Genetic instability and atherosclerosis: can somatic mutations account for the development of cardiovascular disease? Environ Mol Mutagen 35:265-269

Andreassi MG, Botto N, Rizza A, Colombo MG, Palmieri C, Berti S, Manfredi S, Masetti S, Clerico A, Biagini A (2002) Deoxyribonucleic acid damage in human lymphocytes after percutaneous transluminal coronary angioplasty $\mathbf{J}$ Am Coll Cardiol 40:862-868

Benditt EP, Benditt JM (1973) Evidence for a monoclonal origin of human atherosclerotic plaques. Proc Natl Acad Sci USA 70: $1753-1756$

Bennett T, Bennet MR (2001) Reactive oxygen species: oxidative DNA damage in atherosclerosis. Cir Res 88:648-650
Blount BC, Mack MM, Wehr CM, MacGregory JT, Hiatt RA, Wang G, Wickramasinghe SN, Everson RB, Ames BN (1997) Folate deficiency causes uracil misincorporation into human DNA and chromosome breakage: implication for cancer and neuronal damage. Proc Natl Acad Sci USA 94:3290-3295

Botto N, Rizza A, Colombo MG, Mazzone AM, Manfredi S, Masetti S, Clerico A, Biagini A, Andreassi MG (2001) Evidence for DNA damage in patients with coronary artery disease. Mutat Res 493:23-30

Breteler MM (2000) Vascular involvement in cognitive decline and dementia. Epidemiologic evidence from the Rotterdam Study and the Rotterdam Scan Study. Ann N Y Acad Sci 903: 457-465

Chen Z, Karaplis AC, Ackerman SL, Pogribny IP, Melnyk S, Lussier-Cacan S, Chen MF, Pai A, John SW, Smith RS, Bottiglieri T, Bagley P, Selhub J, Rudnicki MA, James SJ, Rozen R (2001) Mice deficient in methylenetetrahydrofolate reductase exhibit hyperhomocysteinemia and decreased methylation capacity, with neuropathology and aortic lipid deposition. Hum Mol Genet 10:433-443

Crott JW, Fenech M (1999) Effect of vitamin C supplementation on chromosome damage, apoptosis and necrosis ex vivo. Carcinogenesis 20:1035-1041

Crott, J, Fenech M (2001) Preliminary study of the genotoxic potential of homocysteine in human lymphocytes in vitro. Mutagenesis 16:213-217

Crott JW, Mashiyama ST, Ames BN, Fenech MF (2001a) Methylenetetrahydrofolate reductase C677T polymorphism does not alter folic acid deficiency-induced uracil incorporation into primary human lymphocyte DNA in vitro. Carcinogenesis 22: 1019-1025

Crott JW, Mashiyama ST, Ames BN, Fenech M (2001b) The effect of folic acid deficiency and MTHFR C677T polymorphism on chromosome damage in human lymphocytes in vitro. Cancer Epidemiol Biomarkers Prev 10:1089-1096

De Flora S, Izzotti A, Walsh D, Degan, P, Petrilli GL, Lewtas J (1997) Molecular epidemiology of atherosclerosis. FASEB J 11:1021-1031

Esteller M, Garcia A, Martinez-Palones JM, Xercavins J, Reventos J (1997) Germ line polymorphisms in cytocrome-P450 1A1 (C4887 CYP1A1) and methylenetetrahydrofolate reductase (MTHFR) genes and endometrial cancer susceptibility. Carcinogenesis 18:2307-2311

Fenech M (1993) The cytokinesis-block micronucleus technique and its application to genotoxicity studies in human population. Environ Health Perspect 101:101-107

Fenech M (2001) The role of folic acid and vitamin B12 in genomic stability of human cells. Mutat Res 475:57-67

Fenech M, Dreosti IE, Rinaldi JR (1997) Folate, vitamin B12, homocysteine status and chromosome damage rate in lymphocytes of older men. Carcinogenesis 18:1329-1336

Fenech M, Aitken C, Rinaldi JR (1998) Folate, vitamin B12, homocysteine status and chromosome damage in young Australian adults. Carcinogenesis 19:1163-1171

Fletcher O, Kessling AM (1998) MTHFR association with atherosclerotic vascular disease? Hum Genet 103:11-21

Friso S, Choi SW, Girelli D, Mason JB, Dolnikowski GG, Bagley PJ, Olivieri O, Jacques PF, Rosenberg IH, Corrocher R, Selhub $\mathrm{J}$ (2002) A common mutation in the 5,10-methylenetetrahydrofolate reductase gene affects genomic DNA methylation through an interaction with folate status. Proc Natl Acad Sci USA 99:5606-5611

Frosst P, Blom HJ, Milos R, Gryette P, Sheppard CA, Matthews RG, Boers GJH, Heijer M den, Kluijtmans LAJ, Heuvel LP van den, Rozen R (1995) A candidate genetic risk factor for vascular disease: a common mutation in methylenetetrahydrofolate reductase. Nat Genet 10:111-113

Gershoni-Baruch R, Dagan E, Israeli D, Kasinetz L, Kadouri E, Friedman E (2000) Association of the C677T polymorphism in the MTHFR gene with breast and/or ovarian cancer risk in Jewish women. Eur J Cancer 36:2313-2316 
Huang RF, Huang SM, Lin BS, Wei JS, Liu TZ (2001) Homocysteine thiolactone induces apoptotic DNA damage mediated by increased intracellular hydrogen peroxide and caspase 3 activation in HL-60 cells. Life Sci 68:2799-2811

Izzotti A, Cartiglia C, Lewtas J, De Flora S (2001) Increased DNA alterations in atherosclerotic lesions of individuals lacking the GSTM1 genotype. FASEB J 15:752-757

Jacques PF, Bostom AG, Williams RR, Ellison RC, Eckfeldt JH, Rosenberg IH, Selhub J, Rosen R (1996) Relation between folate status, a common mutation in methylenetetrahydrofolate reductase, and plasma homocysteine concentrations. Circulation 93:7-9

Kluijtmans LA, Kastelein JJ, Kastelein J, Lindemans J, Boers GH, Heil SG, Bruschke AV, Jukema JW, Heuvel LP van den, Trijbels FJ, Boerma GJ, Verheugt FW, Willems F, Blom HJ (1997) Thermolabile methylenetetrahydrofolate reductase in coronary artery disease. Circulation 96:2573-2577

Kruman II, Culmsee C, Chan SL, Kruman Y, Guo Z, Penix L, Mattson MP (2000) Homocysteine elicits a DNA damage response in neurons that promotes apoptosis and hypersensitivity to excitotoxicity. J Neurosci 20:6920-6926

Lee SH, Blair IA (2001) Oxidative DNA damage and cardiovascular disease. Trends Cardiovasc Med 11:148-155

Loscalzo J (1996) The oxidant stress of hyperhomocysteinemia. J Clin Invest 98:5-7

Ma J, Stampfer MJ, Giovannucci E, Artigas C, Hunter DJ, Fuchs C, Willett WC, Selhub J, Hennekens CH, Rozen R (1997) Methylenetetrahydrofolate reductase polymorphism, dietary interactions, and risk of colorectal cancer. Cancer Res 57:1098-1102

Mager A, Lalezari S, Shohat T, Birnbaum Y, Adler Y, Magal N, Shohat M (1999) Methylenetetrahydrofolate reductase genotypes and early-onset coronary artery disease. Circulation 100 : 2406-2410

Miller JW (2000) Homocysteine, Alzheimer's disease, and cognitive function. Nutrition 16:675-677

Martinet W, Knaapen MW, De Meyer GR, Herman AG, Kockx MM (2002) Elevated levels of oxidative DNA damage and DNA repair enzymes in human atherosclerotic plaques. Circulation 106:927-932

Morita H, Taguchi J, Kurihara H, Kitaoka M, Kaneda H, Kurihara Y, Maemura K, Shindo T, Minamino T, Ohno M, Yamaoki K, Ogasawara K, Aizawa T, Suzuki S, Yazaki Y (1997) Genetic polymorphism of 5,10-methylenetetrahydrofolate reductase (MTHFR) as a risk factor for coronary artery disease. Circulation 95:2032-2036

Piyathilake CJ, Macaluso M, Johanning GL, Whiteside M, Heimburger DC, Giuliano A (2000) Methylenetetrahydrofolate reductase (MTHFR) polymorphism increases the risk of cervical intraepithelial neoplasia. Anticancer Res 20:1751-1757
Povey S, Lovering R, Bruford E, Wright M, Lush M, Wain H (2001) The HUGO Gene Nomenclature Committee (HGNC). Hum Genet 109:678-680

Ross JS, Stagliano NE, Donovan MJ, Breitbart RE, Ginsburg GS (2001) Atherosclerosis and cancer: common molecular pathways of disease development and progression. Ann N Y Acad Sci 947:271-292

Ross R (1999) Atherosclerosis-an inflammatory disease. N Engl J Med 340:115-126

Singal R, Ginder GD (1999) DNA methylation. Blood 93:40594070

Skibola CF, Smith MT, Kane E, Roman E, Rollinson S, Cartwright RA, Morgan G (1999) Polymorphisms in the methylenetetrahydrofolate reductase gene are associated with susceptibility to acute leukemia in adults. Proc Natl Acad Sci USA 96: $12810-12815$

Snedecor G, Cocharn W (1980) One-way classifications; analysis of variance. In: Snedecor G, Cocharn W (eds) Statistical methods, 7th edn. Iowa State University Press, Des Moines, pp 215237

Song C, Xing D, Tan W, Wei Q, Lin D (2001) Methylenetetrahydrofolate reductase polymorphisms increase risk of esophageal squamous cell carcinoma in a Chinese population. Cancer Res 61:3272-3275

Starkebaum G, Harlan JM (1986) Endothelial cell injury due to copper-catalyzed hydrogen peroxide generation from homocysteine. J Clin Invest 77:1370-1376

Stern LL, Mason JB, Selhub J, Choi SW (2000) Genomic DNA hypomethylation, a characteristic of most cancers, is present in peripheral leukocytes of individuals who are homozygous for the C677T polymorphism in the methylenetetrahydrofolate reductase gene. Cancer Epidemiol Biomarkers Prev 9:849-853

Thambyrajah J, Townend JN (2000) Homocysteine and atherothrombosis-mechanisms for injury. Eur Heart J 21:967-974

Ulvik A, Evensen ET, Lien EA, Hoff G, Vollset SE, Majak BM, Ueland PM (2001) Smoking, folate and methylenetetrahydrofolate reductase status as interactive determinants of adenomatous and hyperplastic polyps of colorectum. Am J Med Genet 101:246-254

Van Schooten FJ, Hirvonen A, Maas LM, De Mol BA, Kleinjans JC, Bell DA, Durrer JD (1998) Putative susceptibility markers of coronary artery disease: association between VDR genotype, smoking, and aromatic DNA adduct levels in human right atrial tissue. FASEB J 12:1409-1417

Wenstrom KD, Johanning GL, Owen J, Johnston KE, Acton S, Tamura T (2000) Role of amniotic fluid homocysteine level and of fetal 5,10-methylenetetrahydrafolate reductase genotype in the etiology of neural tube defects. Am J Med Genet 90: 12-16 